\title{
Investigating Factors Affecting Halal Foodpreneur Orientation
}

\author{
Muhammad Dharma Tuah Putra Nasution ${ }^{1 *}$, Yossie Rossanty ${ }^{2}$, Surya Nita ${ }^{3}$, Vita Cita Emia \\ Tarigan $^{4}$ \\ \{dharma_nasution@dosen.pancabudi.ac.id\} \\ ${ }^{1,2,3,4}$ Faculty of Social Science, Universitas Pembangunan Panca Budi, Medan, Indonesia
}

\begin{abstract}
Halal has become a trend and grew its market in business and world trade. Local and global halal markets are opportunities for small businesses that focus on the food business to fill halal market space.This study aims to investigate the influence of religiosity, halal integrity and Islamic values on Halal Foodpreneur Orientation. This research uses a quantitative approach formed by some concepts and hypotheses before collecting field data. Data collection using structured questionnaires and distributed by enumerator team. The research findings proved that religiosity, halal integration, and Islamic values have the significant effect on Halal Foodpreneur Orientation partially. Similarly, the results of the other conclusions indicate that simultaneously the three independent variables referred to affect Halal Foodpreneur Orientation.
\end{abstract}

Keywords: Islamic Values, Religiosity, Halal Integrity, Halal Foodpreneur, Halal Orientation.

\section{Introduction}

The popularity of halal products is increasingly booming, and opens the golden opportunity for more prospective halal business development, especially in Indonesia. As a country with the largest Muslim population in the world, Indonesia fills the first ranks as the largest consumer of halal products in the food and beverage sector, with the total expenditure of food and drink sector of USD155 billion. Unfortunately, the development of halal lifestyle in Indonesia is still stable compared to other countries. This case is based on the report of Global Islamic Economy Report 2017-2018 which showed Indonesia's rank was down to eleven positions compared to the previous year 2015-2016 which is number ten position. Halal business can be interpreted as a business development based on Islamic law, and it was starting from food products, medicines, fashion, cosmetics, tourism, and finance. Halal products have become a world phenomenon, and all countries compete to reach the golden opportunity of halal business. Even non-Muslim majority countries such as Thailand, Korea, and Japan alone are; currently, they were pursuing product standardization to obtain the halal label intensively. The uniformity of halal products ensures Muslims that halal products are healthier and safer for health, Halal is a spiritual necessity, as a dynamic and cyclical process as a final decision (Wilson and Liu, 2011). In the Law Number 33, the Year 2014 explained that halal products are the products are declared halal if they have been by Islamic Shari'a. Naturally, this Law explained the purpose of halal products are to provide consumers felt comfortable, safety, certainty, and confidence. Confidence and belief are not merely the flavors and attractive appearance of a product, but the transparency about the origin of the material, the production process, therefore business owners are concerned about the halal product supply chain. (Zulfakar, 2014b). Thus, to provide a halal belief of a product by the consumers, the business owner obeys the halal standard of the product, starting from the 
necessary ingredients, the process, the packing, the delivery up to the consumers for consumption. (Mohamad and Backhouse, 2014).

The study conducted by (Muhammad et.all, 2013) suggests that business owners who are obedient to Islamic law, believe that halal-certified products evidence halal standards. Halal standards show that the quality of clean and healthy and trusted products (Rafiki, 2014). Unfortunately, most of the business owners are not encouraged to seek halal certification. This case is due to the assumption from business owners that the benefits of halal cannot yet be interpreted into the development of business (Yusuf, 2016). Business owners should realize that halal certificates can be a strategy to attract new customers and keep existing customers. Besides being a device to generate more sales. Look at how high demand for halal products in several European countries are growing. This evidence shows, Europeans are aware of healthy products that produced by a halal process (Rafiki, 2014). Several previous studies have investigated the halal concepts for businesses and industries such as for the food products development (Mohamad and Backhouse, 2014). Halal as an effort to increase business growth for the food industry (Yusuf, 2016). Halal is a strategy to attract new customers to business owners (Rafiki, 2014). Halal indicate the transparency and integrity of the halal in an industrial supply chain (Zulfakar, 2014b). Based on previous studies and the development of Halal food business, the authors proposed to investigate what factors affect Halal Foodpreneur Orientation.

\section{Literature Review}

\subsection{Halal Context}

Muslims always have avoided risks in opposition to Islamic Values. Muslims will be careful before they believe the products for consumption do not violate the provisions of Islamic sharia. Hence, the need for Halal as a manifestation of Muslim obedience on the command of Allah SWT (shariah compliance). Halal has a comprehensive standard as a way to protect consumers. The Halal concept is known as the " Halalan Thoyyiban " which means there are goodness and truth which includes a halal product. Halal is related to a permissible, and as an absolute requirement for Muslims (Nasution, 2018). Halal food awareness is based on the consumer's primary concern for the health. The study by (Bakar and Ambali, 2014) shows that the largest contributor to the level of halal food awareness by the community is healthy and safe. Halal reflects products for consumption are health, hygienic, cleanliness and safe. (Nasution, 2018).

\subsection{Religiosity}

The potential factors influence people to adopt the concept of halal and Shariah principles are shown on knowledge of halal and religiosity (Johan, 2016). Religiosity has a major impact on community values, habits and attitudes and lifestyles. As fundamental to influence behavior in society (Shah Alam, 2011). Commitment to religiosity refers to an individual adherence to religious values, beliefs, and behavior should rely on Islam (Nasution, 2018). As Muslims, the understanding of religious values is shown from their ritual worship as evidenced by the belief in the positive impact of halal products. In fact, this impact has already led to their business goals (Rafiki, 2014). Based on previous studies the authors develop the following hypothesis:

H1; Religiosity positively has a significant effect on Halal Foodpreneur Orientation

\subsection{Halal Integrity}


The system and procedures for handling halal food products require commitment and trust from all parties to ensure the integrity of halal products. The integrity of halal food products must be protected through the necessary stages and involving all stakeholders in the supply chain (Zulfakar, 2014). It intended as an effort to prevent and avoid crosscontamination and affect the product to be unlawful or haram. Thus, the business owner should be more considerate in the process of production which includes activities to receive, store and deliver products to ensure halalness of the food produced (Zailani, 2015). Based on previous studies the authors develop the following hypothesis:

H2: Halal integrity positively has a significant effect on Halal Foodpreneur Orientation

\subsection{Islamic Values}

The study by (Muhammad et.all, 2013) revealed that the Islamic concept of business emphasizes the balance of material and spiritual needs. This balance will have an impact on the continuity of business activities to grow and increase rapidly. Through Islamic Values, business owners will understand business ethics that will guide them to obey the rules that are allowed or prohibited in a business. In addition to business ethics, the motivation of business owners must follow the rules of Islam. In a study by (Yusuf, 2016) confirms that the motivation of business owners to follow Islamic rules aims to develop the business they control. The purpose of business development as a form of product innovation by providing halal products. The real manifestation of business owners adheres to Islamic Value as a business value is a product that already has a halal labeled (Rafiki, 2014). For example, in Malaysia, halal food labeled products are differentiation of products that enable businesses to compete globally (Tawil et.all, 2015). Based on this exposure, the authors developed the following hypotheses:

H3: Islamic Values positively has a significant effect on Halal Foodpreneur Orientation H4: Religiosity, Halal Integrity, and Islamic Values simultaneously affect Halal Foodpreneur Orientation

\section{Research Method}

This study used quantitative approach formed by some concepts, and hypotheses before collecting field data. This study aims to examine the causal relationship between independent variables and dependent variables. Based on the classification, this study is explanatory, and the aims are to test the hypothesis about the causal relationship of various variables studied (Malhotra, 2006). The sampling technique used in this research was accidental sampling. The number of samples in this study that meets the requirements is 414 respondents. Data collection using structured questionnaires and distributed by enumerator team. Data analysis using multiple linear regression after fulfilling the quality of data test, assumption test, and hypothesis test.

\section{Results And Discussion}

\subsection{Characteristics of Respondents}

Characteristics of respondents include socioeconomic consists of age, education, and income of a business. The following are shown some characteristics. 
Table 1. Characteristics of Respondents.

\begin{tabular}{lrr}
\hline \multicolumn{1}{c}{ Characteristics } & \multicolumn{1}{c}{ Frequency } & Percentage \\
\hline $25-29$ & 26 & 6.3 \\
\hline $30-34$ & 58 & 14.1 \\
\hline $35-39$ & 43 & 10.4 \\
\hline $40-44$ & 88 & 21.6 \\
\hline $45-49$ & 84 & 20.3 \\
\hline $50-55$ & 75 & 18.1 \\
\hline$>55$ & 40 & 9.7 \\
\hline Total & 414 & 100 \\
\hline \multicolumn{1}{c}{ Education } & & \\
\hline JHS & 18 & 4.3 \\
\hline SHS & 171 & 41.3 \\
\hline Diploma & 81 & 19.6 \\
\hline Bachelor & 141 & 34.1 \\
\hline Total & 414 & 100 \\
\hline Income of Business & & \\
\hline $5.000 .000-15.000 .000$ & 92 & 22.2 \\
\hline $15.000 .001-.25 .000 .000$ & 184 & 44.4 \\
\hline$>25.000 .001$ & 138 & 33.3 \\
\hline Total & 414 & 100 \\
\hline
\end{tabular}

\subsection{Validity test}

All statements to measure the variables in this study have a correlation value higher than 0.3 . The results of this test prove that all items of the statement are valid.

Table 2. Validity Test Result.

\begin{tabular}{lrrc}
\hline \multicolumn{1}{c}{ Instruments of Variable } & $\begin{array}{c}\text { coefficients } \\
\text { correlation }\end{array}$ & r-table & Result \\
\hline Religiosity $\left(\mathrm{X}_{1}\right)$ & & & \\
\hline X1.1. & .560 & .101 & Valid \\
\hline X1.2. & .587 & .101 & Valid \\
\hline X1.3. & .462 & .101 & Valid \\
\hline X1.4. & .464 & .101 & Valid \\
\hline X1.5. & .459 & .101 & Valid \\
\hline X1.6 & .386 & .101 & Valid \\
\hline X1.7 & .387 & .101 & Valid \\
\hline X1.8 & .334 & .101 & Valid \\
\hline Halal Integrity $\left(\mathrm{X}_{2}\right)$ & & & \\
\hline X2.1. & .573 & .101 & Valid \\
\hline X2.2. & .496 & .101 & Valid \\
\hline X2.3. & .685 & .101 & Valid \\
\hline X2.4. & .470 & .101 & Valid \\
\hline X2.5. & .308 & .101 & Valid \\
\hline X2.6 & .547 & .101 & Valid \\
\hline
\end{tabular}




\begin{tabular}{lccc}
\hline \multicolumn{1}{c}{ Instruments of Variable } & $\begin{array}{c}\text { coefficients } \\
\text { correlation }\end{array}$ & r-table & Result \\
\hline Islamic Values $\left(\mathrm{X}_{3}\right)$ & .617 & .101 & Valid \\
\hline X3.1. & .484 & .101 & Valid \\
\hline X3.2. & .498 & .101 & Valid \\
\hline X3.3. & .542 & .101 & Valid \\
\hline X3.4. & .629 & .101 & Valid \\
\hline X3.5. & .523 & .101 & Valid \\
\hline X3.6 & .634 & .101 & Valid \\
\hline X3.7. & .573 & .101 & Valid \\
\hline X3.8. & .470 & .101 & Valid \\
\hline X3.8. & .547 & .101 & Valid \\
\hline X3.10. & .494 & .101 & Valid \\
\hline X3.11 & .357 & .101 & Valid \\
\hline X3.12 & & & \\
\hline Halal Foodpreneur & & & \\
Orientation(Y) & .556 & .101 & Valid \\
\hline Y.1. & .511 & .101 & Valid \\
\hline Y.2. & .571 & .101 & Valid \\
\hline Y.3. & .445 & .101 & Valid \\
\hline Y.4. & .448 & .101 & Valid \\
\hline Y.5. & .359 & .101 & Valid \\
\hline Y.6 & & & \\
\hline
\end{tabular}

\subsection{Reliability Test}

Cronbach's Alpha correlation coefficient value is higher than data reliability requirement $(>0.6)$. The result indicates that the questionnaire in this study has qualified reliability.

Table 3. Reliability Test Result.

\begin{tabular}{lcc}
\hline \multicolumn{1}{c}{ Variable } & $\begin{array}{c}\text { Value of } \\
\text { Reliability }\end{array}$ & Result \\
\hline Religiosity $\left(\mathrm{X}_{1}\right)$ & 0,758 & $\begin{array}{c}\text { Reliabl } \\
\mathrm{e}\end{array}$ \\
\hline Halal Integrity $\left(\mathrm{X}_{2}\right)$ & 0,765 & $\begin{array}{c}\text { Reliabl } \\
\mathrm{e}\end{array}$ \\
\hline $\begin{array}{l}\text { Islamic Values } \\
\left(\mathrm{X}_{3}\right)\end{array}$ & 0,850 & $\begin{array}{c}\text { Reliabl } \\
\mathrm{e}\end{array}$ \\
\hline $\begin{array}{l}\text { Halal Foodpreneur } \\
\text { Orientation }(\mathrm{Y})\end{array}$ & 0,745 & $\begin{array}{c}\text { Reliabl } \\
\mathrm{e}\end{array}$ \\
\hline
\end{tabular}

\subsection{Partial Test Result}

Tabel 4. Partial Test Results Coefficients ${ }^{\mathrm{a}}$. Model Unstandardi t zed Coefficients

B Std. Error 


\begin{tabular}{llrrrr}
\hline 1 (Constant) & 4.7 & 2.445 & 1.93 & .057 \\
& 20 & & 0 & \\
\cline { 2 - 5 } Religiosity & .17 & .085 & 2.08 & .040 \\
& 7 & & 5 & \\
\hline Halal & .28 & .087 & 3.29 & .001 \\
Integrity & 5 & & 3 & \\
\hline Islamic & .16 & .047 & 3.44 & .001 \\
Values & 2 & & 6 & \\
\hline
\end{tabular}

Dependent Variable: Halal Foodpreneur Orientation

Here is the hypothesis testing:

H1; Religiosity positively has a significant effect on Halal Foodpreneur Orientation

From the partial test results on the table, t-count from religiosity has a value of 2.085 , and t-table has a value of 1.664. The t-count is higher than t-table with significance value $(a=0.04)$ is smaller than the limit of the significance of 0.05 . The result showed that the hypothesis proposed is proven and accepted.

H2: Halal integrity positively has a significant effect on Halal Foodpreneur Orientation

Based on the partial test result presented, t-count from Halal Integrity has a value of 3.293 is higher than t-table which has a value of 1664 and probability (sig. 0.001) is smaller than the limit of the significance value of 0.05 . The result showed that the hypothesis proposed is proven and accepted.

H3: Islamic values positively has a significant effect on Halal Foodpreneur Orientation

Based on the partial test result showed, Islamic values has the t-count value of 3.446 is higher than the t-table value of 1664 with probability (sig 0.001 ) is smaller than the limit of the significance value of 0.05 . The results showed the hypothesis proposed is proven and accepted.

\subsection{Simultaneous Test Results}

Table 5. Simultaneous Test Results.

\begin{tabular}{llccrc}
\hline Model & df & $\begin{array}{c}\text { Mean } \\
\text { Square }\end{array}$ & F & Sig. \\
\hline 1 & Regressi & 3 & 82.617 & 26.4 & $.000^{\mathrm{a}}$ \\
& & & 14 & \\
\cline { 2 - 6 } & on & & 3.128 & & \\
\cline { 2 - 5 } & Residual & 411 & & & \\
\hline
\end{tabular}

Predictors: (Constant), Religiosity, Halal Integrity, Islamic Values

Dependent Variable: Halal Foodpreneur Orientation

Simultaneous test results:

H4: Religiosity, Halal Integrity, and Islamic Values simultaneously affect Halal Foodpreneur Orientation

The results of this test indicate that the F-count value is 26,414 is higher than the F-table value of 2.72 and significance value 0,000 is smaller than 0.05 . The results showed the hypothesis proposed is proven and accepted. 


\subsection{Multiple Linear Regression}

Table 6. Multiple Linear Regression Model.

\begin{tabular}{lr}
\hline \multicolumn{1}{c}{ Model } & Coefficients \\
\hline Constant & 4.720 \\
\hline Religiosity (X1) & 0.177 \\
\hline Halal Integrity (X2) & 0.285 \\
\hline Islamic Values (X3) & 0.162 \\
\hline
\end{tabular}

Based on the results of data processing, The equation of this research is formulated as follows: $\mathrm{Y}=4.720+0.177 \mathrm{X}_{1}+0.285 \mathrm{X}_{2}+0.162 \mathrm{X}_{3}+\mathrm{e}$

\section{Conclusion}

The purpose of this study is to investigate whether there is the influence of Religiosity, Halal Integration and Islamic Value on Halal Foodpreneur Orientation. These findings show that Partially Religiosity (X1), Halal Integration (X2) and Islamic Values (X3) have the significant effect on Halal Foodpreneur Orientation. The findings show simultaneously the three independent variables affect Halal Foodpreneur Orientation. The authors recognize that there are limitations in this study, the authors did not specify the types of the food business that are limiting in investigations such as restaurant or bakery business.

\section{Acknowledgements}

The authors gratefully acknowledge the financial support from Universitas Pembangunan Panca Budi, and we would like to thank the reviewers for guidance sincerely.

\section{References}

[1] Bakar and Ambali (2014) 'People's awareness on halal foods and products: potential issues for policy-makers.', in Procedia-Social and Behavioral Sciences, p. 121, 3-25.

[2] Johan, Z. J. and P. L. (2016) 'Conceptualizing the Influences of Knowledge and Religiosity on Islamic Credit Card Compliance.', in Procedia Economics and Finance, p. 37 (480-487).

[3] Malhotra, N. K. (2006) Marketing research: An applied orientation. Edited by 5/e. Pearson Education India.

[4] Mohamad and Backhouse (2014) 'A framework for the development of Halal food products in Malaysia.'

[5] Muhammad et.all (2013) 'The concept of business ethics in islamic perspective: an introductory study of Small and Medium Enterprises (SMEs).'

[6] Nasution, R. and (2018) 'Country of origin as a moderator of halal label and purchase behaviour.', Journal of Business and Retail Management Research, 12(2).

[7] Rafiki, A. (2014) 'Determinants on the obtainment of halal certification among small firms.', World Applied Sciences Journal, 32(1), pp. 47-55.

[8] Shah Alam, et. al. (2011) 'Is religiosity an important determinant on Muslim consumer behaviour in Malaysia?', Journal of Islamic Marketing, 2(1), pp. 83-96.

[9] Tawil et.all (2015) 'An overview of foodpreneur awareness among Small and Medium-Sized Enterprises (SME) of halal certification. Asian Social Science.', 11(21), p. 91. 
[10] Wilson and Liu (2011) 'The challenges of Islamic branding: navigating emotions and halal.', Journal of Islamic Marketing, 2(1), pp. 28-42.

[11] Yusuf, . et.all (2016) 'Halal certification vs Business growth of food industry in Malaysia.', Journal of Economics, Business and Management, 4(3), pp. 247-251.

[12] Zailani, et. al. (2015) 'Drivers of halal orientation strategy among halal food firms.', British Food Journal, 117(8), pp. 2143-2160.

[13] Zulfakar, et. al. (2014a) 'Conceptual framework on halal food supply chain integrity enhancement.', in Procedia-Social and Behavioral Sciences, pp. 121, 58-67. 